\title{
Assessment of Mobile Applications and its Uses for Home Makers.
}

\section{S. Habeeb Ur Rahaman, S. Janet Mary}

\begin{abstract}
Digital technology development has made a wide demand for smart phones and its applications. The use of mobile applications is needed for all the fields. Mobile applications makes the works easy and simple. The advantage of mobile applications is to reduce the usage of computer and laptop and also the time of travelling to different places. Mobile applications are used with the help of internet. Google play store offers many mobile applications for different purpose for all the users who use smartphones. The usage of smart phones are necessary for both working and home making women. However home makers are in need of mobile applications to do their work easy and fast from home. The mobile applications that are widely used in India for doing home making works like shopping for home, banking, communication and services. In this research we are going to analyse the mobile applications that are useful for home makers to do their home making works from home without travelling to any places. Content analysis method is used for analysing the mobile applications. The mobile applications which are verified by google play store will be selected and analysed. The analysis will report on the usage of mobile applications, features and need for mobile applications. The analysed applications list will be shown in table format. Thus through this research we can find which are the mobile applications that will help home makers in doing their home making work.

Key Words: Mobile applications, Home Makers, Smart phones,
\end{abstract} Internet, Google

\section{INTRODUCTION}

Smartphone inventions are the main source for the development of mobile applications. The mobile phone which are used in 90's also has mobile applications but of those applications are not widely used by the mobile users. The mobile applications are same as like software's used in computers. The term Mobile App was stated from 2010 where app refers to software. The development of smart phone created more demand on the mobile applications. There are different types of applications for different uses like social media, entertainment, education, commerce etc. smart phones are used by most of the people where they are connected to the world through internet. A smart phone can do all sorts of basic work as like a personal computer does. The development of tablet phone and laptops are also created more demand for the software's. Mobile applications are used in e-commerce for online selling and buying process where instead of using a website in personal computer the user can use a mobile application to search products and order them to their respective place by paying online. Mobile application in banking helps people to do all sorts of banking process through their smartphones. So the people who travel to banks has been reduced due to banking related mobile applications.

Revised Manuscript Received on June 13, 2020.

* Correspondence Author

S. Habeeb Ur Rahaman, Research Scholar, Department of Visual Communication, Sathyabama Institute of Science and Technology, Chennai, India.

Dr. S. Janet Mary, Assistant Professor, Department of Visual Communication, Sathyabama Institute of Science and Technology, Chennai, India.

(c) The Authors. Published by Blue Eyes Intelligence Engineering and Sciences Publication (BEIESP). This is an open access article under the CC BY-NC-ND license (http://creativecommons.org/licenses/by-nc-nd/4.0/)
The mobile applications created demand to the social networking apps where people started using the social networks using smartphone then later mobile applications for social networks like whatsapp, Instagram, telegram are created. So these application helps the smart phone users to communicate with each other via text and audio message. Then it was later developed to share images, audio, video and document messages through this applications. Google provides various facilities through mobile applications such as google maps. The application google maps helps people to find out route to the new address which they want to reach. The business companies provide mobile application facility to promote their product and to keep their costumer in touch with the company. The food selling companies and hotels provide mobile applications to order the food online and to track the delivery of food. Mobile applications also play a vital role in education. Many school have provided mobile application to the parents to know about the students daily work and exam schedules. The online education institutions also provide mobile applications to educate the students from home. Using these application the students study their notes and watch videos of their subject's practical demonstrations. Mobile applications are more used by youngsters in games. The developed version of games that connect the youngsters from all the places through internet. Thus the development of smart phones requires more developed mobile applications to full fill the demand of the users.

\section{HOMEMAKERS AND MOBILE APPLICATIONS}

Mobile application are useful for both male and female smartphone users. Mobile applications provide all e-services to the users to complete their work from their places. Home makers are also in need of mobile applications to do their works from home instead of travelling to a specific places. Make home makers travel to shops to buy their groceries and other households but today the technology has made the people to be in their places and order things through online using mobile applications. While comparing to the earlier generation many home makers use to travel too many places daily to do their works but today the technology growth has changed the scenario. The fast moving days and new innovations make people to follow it accordingly to change their lifestyles. Home makers are needed of mobile applications to do their works such as banking, bill payments, shopping of households, ordering of foods, booking transports like taxi, auto rickshaw etc. They also need of some applications like google maps to find their locations while travelling. Home makers must need a smartphone to access the mobile applications.

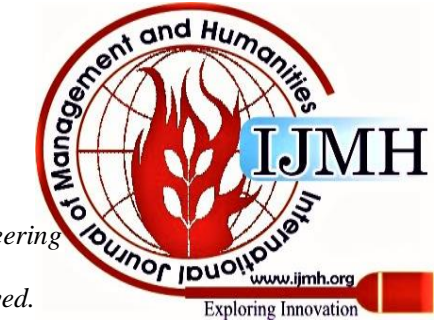


There are some most preferred applications which will be useful for the home makers to do their work. The use of smart phones and mobile applications for the home makers is to do their work by their own when they stay in home with the support of their husband and children. Thus smartphone applications are always useful for the home makers to their works.

\section{LITERATURE REVIEW}

According to Aditi Bhushan (2018) research on Impact of Social Media on Indian Society towards Women says that social media has made many changes in the Indian society. Social media is playing a major role in making women to get educate about what is happing around the world. The research also gives information on government initiatives for women safety and education for women. There are some application which are introduce by the government in concern with the development of rural women in India.

According to Jayaseelan R (2015) research on Usage of Smartphone Apps by Women on their Maternal Life says that women are using smartphone while they are in pregnant and some of them use mobile health applications to check their daily health. The usage of smart phone is common in both before pregnancy and after pregnancy stages. The research also says that women from the middle class families uses more smart phones and mobile applications than men. According to Kapil Sharma (2016) research on online medicines and medical products shopping - a brief study says that buying of medical products through online will increase in future. Most of them prefer this method of shopping is due to save the time and travel expenses. There are some medical product companies which is also providing offers as like other commercial products. So to avail the cash discounts and offers some of them prefer to go for online shopping for medical products. As like other products medical products are also delivered by the concerned seller thus it is a benefit for online buyers. According to Ms.Kavitha (2017) research A Study on Consumers acuity towards online grocery shopping says that majority of people select to shop groceries online because they can shop any time. They prefer this online mode of grocery shopping is due to cash less transactions and home delivery options that are provided by the sellers. Most of the people prefer to buy health care products through online. It is also noted by the researcher that most of the people purchase their groceries weekly. According Dr. Nishi Bhardwaj (2019) research on paytm usage says that through advertisements more than $50 \%$ of the people are aware of paytm and they use it for their financial transactions. The major use of paytm is for mobile recharge purpose. The offers such as cashback is mainly attracting the customers to use paytm. It has become one of most popular digital wallet of people in India. According to Mr. R Renjan (2019) research on perception of smartphone users towards mobile payment system says that smartphone users have adopt the mobile payment method for their financial transactions. Payment applications like google pay is used by $40 \%$, paytm by $35.2 \%$, phonepe by $5.2 \%$ followed by freecharge $4.3 \%$ and mobiwik at .5\%. It is noted that smartphone users find easy and fast way for payments using these applications. The offers provided by the payment application services has become a deciding strategy for the users to select which application to use for selected payments.
According to Mr.Sagar Brid (2017) research on mobile banking application usage in various sectors of society says that mobile application for payment is used widely. Most of the people prefer to private mobile applications. Mobile wallet is getting more popular among people this will also leads to select different payment applications that are available. Though there are more number of applications available most of the people prefer paytm application.

According to Ms.Siddhi Agrawal (2018) research on online shopping through desktop \& mobile application: a comparative study says that the usage of online website through desktop is equal to those who use mobile application for shopping. Through the research it was found that most of the people are aware of the mobile shopping applications and they prefer them based on the products that are available. According to Dr. Sonali Jadhav (2018) research on Food Ordering Mobile Applications - A new wave in food entrepreneurship says that most of the people in India started ordering food through online. The usage of smartphones and mobile applications are the major factors of online food ordering. Around $87 \%$ of restaurant have mobile applications for their costumers to order food. To speak on the effectiveness of food delivery through mobile applications it was said that $50 \%$ people says that it effective in ordering of food through online and it reach them correctly. The expectation of people is that through ordering of food online they can also reduce the cost while it was deliver to their home. According to Tanzila Ayaz Sayed (2018) research on customer satisfaction in using E-payment app services says that paytm has taken the major part of the E-payment sector whereas compare to the other BHIM applications. The research conducted in Pune city in India shows that $74 \%$ of market shares in E-payment was occupied by the Paytm application. Around 83\% of costumers using paytm service says that they are satisfied in using the application. They are many government offered payment application available but $79 \%$ of them says that they feel better in using paytm compare to the other government apps.

\section{METHODOLOGY}

The research is carried out with content analysis method. Through this method we can analyse the mobile applications. Mobile applications which are useful for home making will be selected and analysed.

\section{A. Analysis of mobile application}

Mobile applications that are verified by the google play store and the applications which has the feature to do house works will be selected for analysis. The selected mobile applications will be installed in a smart phone. The functions of mobile applications will be analysed by accessing the applications. Through login process the applications will be opened and the functions of application will be checked. The analysis mainly focused on the need of home makers. The functions of each and every selected application will be noted and checked for the home makers requirement. 
The mobile applications which are widely used in India for house works, banking, and commerce will be only selected for analysis. The analysis report will be prepared in the form of tables representing the details of mobile applications.

\section{FINDINGS}

Table -I: Mobile applications need for Homemakers

\begin{tabular}{|c|c|c|c|}
\hline SL.No & $\begin{array}{c}\text { Applications } \\
\text { Name }\end{array}$ & Functions & Need for Application \\
\hline 1. & $\begin{array}{l}\text { Google } \\
\text { Chrome }\end{array}$ & $\begin{array}{l}\text { Browser / } \\
\text { Search } \\
\text { Engine of } \\
\text { Internet }\end{array}$ & $\begin{array}{l}\text { Home Makers can search any } \\
\text { sorts of information using this } \\
\text { search engine. They can also } \\
\text { log on to any website. }\end{array}$ \\
\hline 2. & Gmail & $\begin{array}{c}\text { Sending and } \\
\text { Receiving } \\
\text { E-mails }\end{array}$ & $\begin{array}{l}\text { Home Makers are need of } \\
\text { Gmail application to receive } \\
\text { mails of purchase bills, } \\
\text { warranty cards of various } \\
\text { products which is purchased } \\
\text { through online shopping. } \\
\text { They can also receive e } \\
\text { statements from bank. }\end{array}$ \\
\hline 3. & Whatsapp & $\begin{array}{l}\text { Social } \\
\text { media } \\
\text { application } \\
\text { that share } \\
\text { text, } \\
\text { images, } \\
\text { videos and } \\
\text { also used } \\
\text { for voice } \\
\text { and video } \\
\text { calls } \\
\text { through } \\
\text { internet. } \\
\end{array}$ & $\begin{array}{l}\text { Home makers can get } \\
\text { connected with their friends } \\
\text { and relatives they can share } \\
\text { the images, videos of various } \\
\text { occasions. They can talk and } \\
\text { live video chat with others. } \\
\text { Home makers can also gain } \\
\text { knowledge of the outer world } \\
\text { happenings through whatsapp } \\
\text { group chats. }\end{array}$ \\
\hline 4 & Youtube & $\begin{array}{l}\text { Social } \\
\text { media } \\
\text { application } \\
\text { that share } \\
\text { videos } \\
\text { related to } \\
\text { google } \\
\text { search. } \\
\end{array}$ & $\begin{array}{l}\text { Home makers can use this } \\
\text { application to watch video of } \\
\text { various choice like cooking, } \\
\text { home decoration, life style, } \\
\text { health tips, life hacks etc. }\end{array}$ \\
\hline 5 & Flipkart & $\begin{array}{l}\text { Online } \\
\text { Shopping }\end{array}$ & $\begin{array}{l}\text { It is easy to shop through this } \\
\text { application they can view the } \\
\text { products and order online. } \\
\text { Products like grocery, } \\
\text { households, medical and } \\
\text { lifestyle can be purchase here. } \\
\text { They can do cashless } \\
\text { transactions }\end{array}$ \\
\hline 6 & Amazon & $\begin{array}{l}\text { Online } \\
\text { Shopping } \\
\quad \& \\
\text { Payment } \\
\text { Service }\end{array}$ & $\begin{array}{l}\text { Homemakers can shop online } \\
\text { products like grocery, } \\
\text { households, medical, lifestyle } \\
\text { etc. and they can pay the } \\
\text { amount through online or as } \\
\text { cash. Home makers can also } \\
\text { link their bank account with } \\
\text { amazon to scan and pay bills } \\
\text { while purchasing products. }\end{array}$ \\
\hline 7 & Phonepe & $\begin{array}{c}\text { Payment } \\
\text { application }\end{array}$ & $\begin{array}{c}\text { Home makers can link their } \\
\text { bank account with this } \\
\text { application to pay School } \\
\text { fees, electricity bill, phone } \\
\text { recharge, DTH recharge, LPG } \\
\text { payment, Municipal Tax, }\end{array}$ \\
\hline
\end{tabular}

\begin{tabular}{|c|c|c|c|}
\hline & & $\begin{array}{l}\text { used for all } \\
\text { kinds of bill } \\
\text { payments } \\
\text { and bank } \\
\text { transactions }\end{array}$ & $\begin{array}{l}\text { Water tax, broad band Bills, } \\
\text { travel booking, restaurant } \\
\text { booking, movie tickets etc. } \\
\text { they can scan and pay with } \\
\text { QR code which available in } \\
\text { the shopping places, Fuel } \\
\text { stations etc. They can send or } \\
\text { receive money to any people } \\
\text { using their bank details. }\end{array}$ \\
\hline 8 & Google pay & $\begin{array}{l}\text { Payment } \\
\text { application } \\
\text { offered by } \\
\text { google for } \\
\text { sending and } \\
\text { receiving } \\
\text { money and } \\
\text { also to pay } \\
\text { bills. }\end{array}$ & $\begin{array}{l}\text { Home makers can use this } \\
\text { application for payment } \\
\text { transfer they can send or } \\
\text { receive payment to any } \\
\text { person who use this same } \\
\text { application by simply } \\
\text { selecting him \her from the } \\
\text { contact list. The application } \\
\text { also provides the facilities to } \\
\text { pay phone bills, travel, hotel, } \\
\text { electricity. Scan and pay } \\
\text { facility is used in shopping, } \\
\text { Fuel stations etc. }\end{array}$ \\
\hline 9 & Paytm & $\begin{array}{l}\text { Payment } \\
\text { application }\end{array}$ & $\begin{array}{l}\text { Home makers can send or } \\
\text { receive payments to same } \\
\text { application users. The } \\
\text { application also provide to } \\
\text { scan and pay in shopping } \\
\text { places. }\end{array}$ \\
\hline 10 & Swiggy & $\begin{array}{c}\text { Food } \\
\text { delivery } \\
\text { from hotels }\end{array}$ & $\begin{array}{l}\text { Home makers can use this } \\
\text { application to order food any } \\
\text { hotels around the city/ town. } \\
\text { The application provides the } \\
\text { facility to know about the } \\
\text { status of delivery through a } \\
\text { road map. }\end{array}$ \\
\hline 11 & Zomato & $\begin{array}{c}\text { Food } \\
\text { delivery } \\
\text { from hotels }\end{array}$ & $\begin{array}{l}\text { Homemaker can order food } \\
\text { through this application. This } \\
\text { application will give } \\
\text { information on various hotels } \\
\text { and restaurants. They can } \\
\text { check the status of the food } \\
\text { delivery. }\end{array}$ \\
\hline 12 & Urban clap & $\begin{array}{l}\text { House hold } \\
\text { services }\end{array}$ & $\begin{array}{l}\text { Home makers can use this } \\
\text { app for house works like } \\
\text { installing or repairing of } \\
\text { electronic household } \\
\text { products, cleaning, painting, } \\
\text { pest protecting. }\end{array}$ \\
\hline 13 & Ola & $\begin{array}{l}\text { To book } \\
\text { car/ auto } \\
\text { rickshaw } \\
\quad \text { for } \\
\text { travelling }\end{array}$ & $\begin{array}{l}\text { Home makers can use this } \\
\text { application to book car / auto } \\
\text { rickshaw to travel anywhere } \\
\text { in around the city or town. }\end{array}$ \\
\hline 14 & $\begin{array}{l}\text { Google } \\
\text { Maps }\end{array}$ & $\begin{array}{l}\text { To provide } \\
\text { road maps, } \\
\text { bus route, } \\
\text { trains and } \\
\text { for } \\
\text { pedestrians }\end{array}$ & $\begin{array}{l}\text { Home makers can use this } \\
\text { application while they travel } \\
\text { outside to any place. They } \\
\text { can find route to travelling } \\
\text { and through this application } \\
\text { they can know the status of } \\
\text { traffic on road based on that } \\
\text { they can select the route. }\end{array}$ \\
\hline
\end{tabular}

Published By: Published By:
Blue Eyes Intelligence Engineering
\& Sciences Publication 


\section{Assessment of Mobile Applications and its Uses for Home Makers.}

The selected applications are more widely used by most of the home makers. There are many different applications which have same functions but the application which was found here are universal. Many banks provide separate applications for their banking process but the applications that are mentioned here are universal which accepts to link all banks. The applications related to social media are more in number but the most widely used application is whatsapp. The application which are mentioned here are more useful to home makers in doing their works in home and outdoor.

\section{CONCLUSION}

Smart phone users create a wide demand in mobile applications as it helps them to do their work easy. Working women will be using more mobile applications to do their work fast as they do their home making and go to office. The number of smartphone users are getting increased every day but still some home makers are depending on their family members to satisfy their daily digital need. However home makers are also in need of mobile application to do their work smart and fast. The use of mobile applications for home makers will reduce the travelling time from their home to other places. They can also save their expense of travelling to places for shopping. They can save time by ordering online and they are also be safe from road traffic, pollution and other illegal activities like robbery etc. The initiatives of government towards making usage of mobile applications such as UPI payment applications and mobile bill payment applications is to encourage the usage of mobile applications and to make the people to adapt towards digital technologies. The research founds that the mobile applications are more necessary for the home makers to do their works easy and safe. There are many mobile applications which are especially designed for women needs. The mobile applications shown above in the table will be useful for the home makers to do their work fast and easy through digital mode. Home makers should start adopting towards the usage of mobile application to do their home making works. Thus mobile applications will be the future need of the home maker when the technologies move to smart homes. The research can be further done on specific mobile applications, uses and difficulties that are faced by home makers.

\section{REFERENCES}

1. Aditi Bhushan (2018) Impact of social media on Indian Society towards Women

2. Jayaseelan R (2015) research on Usage of Smartphone Apps by Women on their Maternal Life

3. Kapil Sharma (2016) research on online medicines and medical products shopping - a brief study

4. Kavitha (2017) research A Study on Consumers acuity towards online grocery shopping

5. Dr Nishi Bhardwaj (2019) A Study on Usage of Paytm

6. R Renjan (2019) Perception of Smartphone users Towards Mobile Payment System an Empirical Study

7. Sagar Brid (2017) Study of mobile banking application usage in various sectors of society

8. Siddhi Agrawal (2018) research on online shopping through desktop \& mobile application: a comparative study

9. Dr. Sonali Jadhav (2018) research on Food Ordering Mobile Applications - A new wave in food entrepreneurship Tanzila Ayaz Sayed (2018) A Study Of Customer Satisfaction Level And Customer Perception of E-Payment App Services with Special Reference to Pune City

\section{Reference Links}

1. https://www.researchgate.net/publication/329687049_Impact_of_Soci al_Media_on_Indian_Society_towards_Women

2. https://www.hilarispublisher.com/open-access/usage-of-smartphoneapps-by-women-on-their-maternal-life-2165-7912-1000267.pdf

3. http://www.iraj.in/journal/journal_file/journal_pdf/14-2341458364281112-113.pdf

4. https://www.researchgate.net/publication/324806028 A Study on C onsumers acuity towards online grocery shopping https://www.ijraset.com/fileserve.php?FID=22435 https://www.ijrte.org/wpcontent/uploads/papers/v8i1/A3403058119.pdf

5. https://www.ijser.org/researchpaper/Study-of-mobile-bankingapplication-usage-in-various-sectors-of-society.pdf

6. https://www.researchgate.net/publication/326929796_Online Shoppi ng through_Desktop_Mobile_Application_A Comparative_Study

7. https://www.ijltemas.in/DigitalLibrary/Vol.7Issue4/110-115.pdf http://ijamtes.org/gallery/503.\%20dec\%20ijmte\%20-\%201349.pdf

\section{AUTHORS PROFILE}

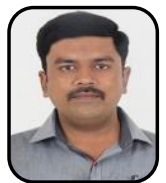

S.Habeeb Ur Rahaman, Research Scholar, Sathyabama Institute of Science and Technology, Chennai. I have completed my BSc Degree in Visua Communication from New College (Autonomous), Chennai and MSc Degree 2010 in Electronic Media from St.Thomas College of Arts and Science in 2012 Currently pursuing $\mathrm{PhD}$ from Sathyabama Institute of Science and Technology. Attended workshop on "Intellectual Property Rights" on $13^{\text {th }}$ Sep/2019.Completed 8 week course on "Introduction to Research" during Aug- Sep 2018. Completed 12 week course on "Qualitative research Methods" during Jan- Apr 2019, Completed 12 week course on "Introduction to Film studies" during Jul- Dec 2019. Attended workshop on SPSS statistical analysis software during Feb-2020.Completed "R Programming" certificate course during Apr- 2020.

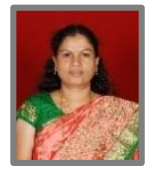

Dr.S.Janet Mary, has been served as the Assistant Professor in the Department of Visual Communication at Sathyabama University, Chennai from 2008 to 2019.Currently working as Assistant Professor at Madras Christian College, Chennai. As a well distinguished scholar with M.A., in Sociology, M.Sc., and M.Phil., in Electronic Media and Communication from the University of Madras, I completed my Ph.D., in Media Reach among fishing community in Cuddalore District of Tamil Nadu in the year 2015 in the Department of Journalism and Communication in Periyar University, Salem. A nation that wants progress cannot afford to ignore capacity building and empowerment of the marginalized has been the objective of her Ph.D., research. Prior to her teaching career she had the privilege of serving the poor and the downtrodden women and children in the remote areas of Bihar. 